\title{
The Fight Against Terrorism
}

\author{
Stevan Aleksoski \\ Professor, "Goce Delchev" University - Shtip, Republic of Macedonia, \\ Faculty of Law \\ Petar Karagjuleski \\ Law student, "Goce Delchev" University - Shtip, Republic of Macedonia, \\ Faculty of Law
}

\begin{abstract}
Cooperation between NATO and the UN last few years is quite extended. NATO and the UN expand their cooperation in the fight against modern terrorism at all levels that act or institutional field, conceptually and politically. Cooperation and consultation between these organizations not only apply to dealing with crisis situations, but their collaboration extends to other issues such as civilmilitary cooperation, the fight against human trafficking, the fight against terrorism, and more. The most important mission of NATO today is the mission in Afghanistan, was established with a mandate from the UN in 2001 and is under the leadership of NATO in August 2003, under the name of ISAF International Security Assistance Force. Challenges that threaten the interests of the Euro-Atlantic alliance are: terrorism, weapons of mass destruction, and the threat of ballistic missiles, conventional armed forces, cyber attacks, energy security and climate change.
\end{abstract}

\section{THE COOPERATION OF NATO AND THE UN IN THE FIGHT AGAINST TERRORISM}

Military-political cooperation and protecting the security of member countries is an essential objective pursued for NATO. NATO provides a lasting and peaceful order worldwide through partnerships and operations management crises in those regions and countries where it is needed. All NATO member countries cooperate with each other to a very high level and ensure that in each case to deal with security challenges no Member State has forced its own national capabilities and can afford to invoke Article 5 of the Washington Treaty, which would mean collective support from the Alliance and its members.

Modern terrorism that has taken an increasingly important role in security in the world especially in the regions of the Middle East and North Africa (and appearance, reasons for existence, funding, technical support, these terrorist organizations is a controversial issue that affects other topics) an incentive to intensify the scope of cooperation between international organizations, particularly between NATO and the UN.

Cooperation in the fight against terrorism between NATO and the UN these international organizations permeate all levels of that act or institutional field, conceptual and political. Fighting terrorism and dealing with crisis situations are just part of the cooperation and consultation of NATO and the UN, and it extends to other issues such as civil-military cooperation, the fight against human trafficking, and destruction of mines and so on.

Link which connects NATO and the UN are best seen from the Preamble of the Washington Treaty (North Atlantic Treaty) where NATO stipulate that the UN Charter is the framework in 
which they operate NATO. The right of the Allies to take certain actions that they believe would be necessary for their individual or collective self-defense is set out in Article 5 of the Washington Treaty, which in turn refers to Article 51 of the UN Charter. This implies the use of military force to stop any kind of aggression or armed attack, as well as taking other measures when the Security Council of the United Nations shall take the measures necessary to restore and maintain international peace and security.

Article 5 of the Washington Treaty specifies: "The Parties agree that an armed attack against one or more of them in Europe or North America shall be considered as an attack against them all and consequently they agree that, if there is such an armed attack occurs, each of them, in exercise of the right of individual or collective self-defense recognized by Article 51 of the Charter of the United Nations, will assist the party or parties attacked by taking forthwith, individually and in concert with the other parties, such action which it deems necessary, including the use of armed force, to restore and maintain the security of the North Atlantic area.

Any such armed attack and all measures taken as a result thereof shall immediately be notified the Security Council. Such measures shall be terminated when the Security Council has taken measures necessary to restore and maintain international peace and security. "

Article 51 of the UN Charter provides: "Nothing under this Charter will not prevent the inherent right of individual and collective self-defense if an armed attack occurs against a member of the United Nations, until the Security Council take the necessary measures to maintain world peace and security. The measures taken in the application of the right of selfdefense members will immediately inform the Security Council and in no case will not affect the action that would have prevented the Security Council on the basis of the Charter to make his authority and responsibility for establishing and maintaining world peace and security."

In terms of cooperation in the fight against terrorism, NATO and the UN in the 21st century can be distinguished several such collaborations realized on the ground. Of course in the fight against modern terrorism and its modern forms is intervention in Afghanistan in which key was a cooperation between NATO and the UN. It can also mention the intervention in Sudan in 2005 in cooperation with NATO, the UN and the EU to stop the violence in Sudan where NATO helped air transport of Peacekeeping troops from African countries, and the training of officers of the African Union.

General Secretary of NATO in terms of progress in the fight against terrorism regularly sends reports to the General Secretary of the United Nations concerning the success of NATO operations, as well as the key decisions of the Alliance. NATO contributes to the work of the Counter Terrorism Committee of the UN and participate in meetings of the Committee. After the attacks on the United States on 11.9.2001, the Security Council established the UN Committee for Terrorism, NATO and participate in special meetings of the Committee and other international, regional and sub-regional organizations involved in the fight against terrorism.

From 1990 to the present legal framework for engagement of NATO is different. Primarily engagements of NATO, as defense alliance, based on Article 5 of the Washington Treaty or the common defense action of all Member States in case of an attack on one member state. Another way appears multilateral NATO action taking place in the framework that sets the Security Council of the UN, as an organization that contributes to peace and stability in the world. A third way of engagement of NATO forces is engagement at the request of a Member State or country partner seeking help. Practically, it can be seen from the following bullet points: 
- NATO's engagement on the basis of Article 5 of the Washington Treaty (Charter) requires rendering the collective help of any NATO member country in the event of military aggression. This was created in this way in order to deter the Soviet Union from a possible military attack on the western countries of Europe. But there was a long period of time while a country not invoke this right. The US were the first invoked Article 5 of the Charter and not because of violation of territorial borders with conventional attack but because of the terrorist attacks. US sought help and support from NATO allies in the global fight against terrorism;

- The engagement of NATO under the auspices of the Security Council of the United Nations began in Bosnia where NATO had a role in keeping the peace, providing logistical support. In Kosovo and Metohia NATO had a similar role as in Bosnia but the attack on Yugoslavia in 1999 there was no formal approval by the Security Council from the UN and NATO, and to justify this action they are called for some UN resolutions related to Kosovo;

- NATO's engagement at the request of a Member State or country as a practice partner is established in 2001, the infamous year of Macedonia. In 2001, NATO was called in the country at the request of the President of the country to help prevent further escalation of the war. This kind of asking for help from NATO create a model in which they conducted several other missions.

\section{THE FIGHT AGAINST TERRORISM}

The terrorist attacks on the United States in 2001 were the reason for the change of geopolitical relations in the world and the US to take the lead in the fight against terrorism globally. Military actions today to pursue US justified by the attacks on certain countries (who, regardless of their political system is sovereign) is because these countries are a source of terrorists or supporting or financing terrorism, and because likely (previously shown evidence is quite controversial and not confirmed allegations especially Iraqi) possess a chemical, biological, radioactive and nuclear weapons that could be used for terrorist attacks on the West course. After the attacks on the US in 2001 sounds and NATO called on Article 5 of the Washington Treaty with the attacks on the US were seen as an attack on all NATO nations, according to the principle of common defense.

The fight against terrorism includes destruction of camps for training terrorists, direct attacks terrorist cells and indirect war. This indirect war against terrorism amounts of research and pressure of governments, organizations and individuals who support terrorist organizations, and means and financial assistance to the countries participating in the anti-terror war, increasing the level of police and intelligence cooperation .

Collective self-defense can be activated by the Member States with a special agreement, and can be activated and the special request of a country that is the victim of an armed attack without any agreement about it. It is important to emphasize that the individual right to selfdefense under Article 51 of the Charter terminated when the Security Council took appropriate action against the attacker. Likewise, the right of self-defense cannot be used to conquer foreign lands or for taking punitive expeditions. State that certain actions are taken in accordance with Article 51 of the Charter is obliged to immediately inform the Security Council on the activities undertaken, thereby triggering its jurisdiction. If it happen to state, that it exercised its right of self-defense does not inform the Security Council on the implementation of the right it creates doubt about the legitimacy of armed intervention. 
The right of military intervention in individual or collective self-defense is permitted if it is constant, the current attack is underway, but to do so it needs to be met several conditions:

First, the use of force to take / is allowed if there is a direct act of the state aggression which invokes Article 51 of the Charter. If there is some indirect intervention such as propaganda, economic aggression and more the use of force for self-defense is not allowed.

Secondly, the seriousness of armed attack makes entitlement to the use of military force for self-defense. Whether performed attack aggressive assessment performed Security Council.

Third, the right of self-defense can only be activated in cases where there is provocation unlawful act. No country can invoke the right of self-defense to introduce coercive measures by the United Nations or against a country which according to Article 51 of the UN Charter and allowed the use of the right of self-defense.

Fourth, proportionality in the use of armed force in self-defense is the next requirement. Power used in self-defense must be proportional to the strength of aggressive attack, otherwise would be surpassed or abuse right of self-defense.

Fifth, under Article 51 of the Charter, self-defense cannot be activated due to an attack in the future to happen, will be happen or will happened. Only if simultaneously place aggressive attacks with the use of armed force for self-defense may be considered self-defense is legal. But in terms of Article 51 of the Charter there disagreement about the interpretation of the section that allows the use of individual force, without the permission of the Security Council of the United Nations, when the attack has not occurred or there is only a threat to its occurrence. According to the US is allowed to use force to prevent future attacks not yet been started, but this claim is based on a common law of self-defense. That the right of self-defense is only activated only when there is an armed attack is confirmed by International Court of Justice which is his attitude.

Sixth, when the Security Council took certain measures against the aggressor, the right of selfdefense moves from individual to collective right of self-defense.

\section{CRISIS MANAGEMENT}

Coping with crisis situations is one of the goals of NATO. Alliance has the experience, capabilities, skills and practice in dealing with different types of crises. In order to be ready any time for crisis management, within the framework of the NATO member states work together every day in that field, allowing members and partners to train and work together on joint operations, missions and programs.

Besides military operations role of NATO goes further and includes addressing certain issues like setting for the protection of the population of technological, humanitarian and natural disasters. Crisis management in certain volatile regions commonly referred to as peacekeeping operations, but there are other types of operations that have specific goals and mandates. Whether NATO will be involved in the resolution of a crisis decides on a case by case basis. That means that the decision, as well as other decisions of the Alliance are made by consensus among the members. Also some operations led by NATO to include countries and cooperating partners who are not members of the Organization and other international organizations. Practical example of a partner country of NATO is the Republic of Macedonia, which has participated in several missions of the Alliance, including the mission ISAF. In mission ISAF participating 49 countries including the Republic of Macedonia with 155 people. Most of the 
participants in this mission have US 33,600, and at least Iceland, Malaysia and New Zealand with 2 participants. The total number of people who participate in the mission of ISAF is 52,686 people. This information concerning the period up to February 20, 2014.

The Alliance's Strategic Concept of 2010 was enacted comprehensive approach to crisis management thus provides for the involvement of NATO in all stages of the crisis and the opportunities to use different ways of solving the crisis, which depends on the nature, extent and severity of the crisis. Sometimes the resolution of crises take place through diplomatic ways, once again require more rigorous measures such as military operations. Article 4 of the Washington Treaty entitles each member state to advise and discuss any safety issue. Article 4 provides: "Members shall consult together in the opinion of any of them is under threat territorial integrity, political independence or security of any State."

\section{Afghanistan}

\section{PART OF THE CURRENT OPERATIONS AND MISSIONS OF NATO}

The most important mission of NATO to today is mission in Afghanistan, which was established with the mandate of the UN in 2001 and is led by NATO in August 2003, as the ISAF International Security Assistance Force. The mission consists of about 50,000 troops from 48 different countries deployed throughout Afghanistan. The main task that has this mission is the spread of power to the Afghan government in order to create an environment conducive to development and functioning democratic institutions and establish the rule of law. Alliance has a major role in the establishment of professional national Afghan security forces to allow Afghans to take responsibility for the security of their country.

The plan by the end of 2014 the ISAF mission in Afghanistan to end with the gradual transition of security responsibilities to the Afghan national security forces and police. However, after this period the mission will continue training and counseling as well as support of combat operations to Afghan forces.

With resolution of the Security Council of the UN 1510, NATO expands its presence in Afghanistan by creating PRT - Provincial Reconstruction Teams. These teams are international teams that have to extend the authority of the central government and to establish a safer environment to carry out reconstruction. The composition of these teams entered civilian and military personnel.

The process of deep reforms after the intervention of the international community in areas such as justice, security and sector democratization in Afghanistan. ISAF forces were involved in the coordination of demobilization, disarmament and reintegration. Regarding disarmament were seized about 9,000 pieces of heavy weapons, about 30,000 light weapons, and about 62,000 soldiers were demobilized.

\section{Kosovo}

NATO entered the territory of Kosovo in 1999 after the bombing of Yugoslavia in order to end the humanitarian crisis and to preserve peace and security. Today Kosovo is about 5,000 Allied soldiers working as part of KFOR NATO forces. Since 2008, when Kosovo declared its independence, the Alliance decided to continue its presence there based on resolution 1244 and assists in the creation of professional and multiethnic Kosovo Security Force.

However, the military intervention of NATO over Yugoslavia in 1999 under the name "Operation Allied Force" (Operation Allied Force) is one of the military interventions that are 
considered illegitimate. For the implementation of this operation is no agreement by the UN Security Council, and the bombing was carried out under the guise of humanitarian intervention.

\section{MONITORING OF THE MEDITERRANEAN SEA}

After the attacks on the United States 11.9.2001 year by NATO were taken a series of measures opposition the threat that came, and still comes from modern international terrorism. In October 2001 was launched Operation Active Endeavour, which direct its focus toward the discovery and refuse terrorist activities in the Mediterranean Sea.

With the increased presence of NATO forces in these waters ensuring safety of vessels carrying passengers and goods, and providing safety and maritime region along the Mediterranean Sea. First, control was implemented only in the eastern waters of the Mediterranean Sea, and since 2004 the entire territory of the Mediterranean Sea. This action took their participation and the forces of "Partnership for Peace" including a Russian cruiser, some members of the "Mediterranean Dialogue" and "and Istanbul Cooperation Initiative".

\section{CHALLENGES FOR NATO}

The challenges that need to handle the Alliance in the years to come do not differ much from those before sixty years ago, when was formed the Alliance, who interested countries on security issues, some challenges still quite new. The challenges that threaten the interests of the Euro-Atlantic community: terrorism, weapons of mass destruction, the threat of ballistic missiles, conventional armed forces, cyber-attacks, energy security and climate change.

- Terrorism is the greatest threat to peace and security and is a major reason for the transformation of NATO, which by all means and forces in cooperation with other international organizations, and a maximum of UN fight against terrorism. Until now the top priority took NATO presence in Afghanistan and the fight against terrorism, and it is an opportunity for the alliance to show and prove their ability to solve complex security issues.

- Weapons of mass destruction is also a priority of the alliance and is connected to terrorists and terrorist organizations. Having the opportunity to purchase and use of this kind of weapons by terrorist organizations is a real threat. Therefore NATO plans to control access to such weapons and its spread, and as the biggest security threat considers the development of the nuclear programs of Iran and North Korea.

- The threat of ballistic missiles there since the creation of NATO and still is one of the more important priorities. Not only large but smaller countries possess ballistic missiles with a range or intercontinental missiles that need to be taken to avoid abuse. In this respect the intent of the United States to deploy air defense in Poland and the Czech Republic where the sharp response and resist Russia feeling threatened by setting these air shields.

- Conventional Armed Forces priority entered again the focus of NATO from 2007 after the attack on Georgia by Russia unilaterally refused to honor the Treaty on Conventional Forces.

- Cyber-attacks with the development of the Internet and modern technology have become a real threat. Cooperation with NATO partners significantly improved thanks to new technologies and the Internet, but there was also the threat of possible terrorist attacks on these technologies and communication systems.

- Energy security is of great importance for NATO. Smooth supply of energy resources such as oil and gas is a challenge in the years ahead. 
- Climate change is one of the focuses of NATO, but by civilian or alliances are trying their capacities and resources to assist in preserving the natural environment.

But as the most specific and most dangerous to preserve world peace this days are the crisis in Ukraine and the creation of a Muslim state of ISIS.

We must also mention the issue of Ukraine as one of the challenges for NATO, which is last month, but for now great interest shown and the Alliance as well as leaders of its member states and the leaders of the US and UK. Every day we are bombarded with a huge amount of information about the situation in Ukraine, fighting between the two sides, military and civilian casualties, devastation of schools and homes, destruction of aircraft and so on. Here it is a delicate situation and the opposition of interests and influences. Whether and how to involve NATO in solving this problem is an issue that deserves attention. Ukraine is at the gates of Russia, and the possible entry of the Alliance in this country is a kind of provocation to Russia which is considered eternal opponent of NATO. The only loser in this fight so far the major powers is only the Ukrainian people who would take decades to recover from this mutual fratricidal war.

\section{ISIS / ISIL}

More specifically solving and opportunity for intervention is the issue with the extremist organization ISIS - Islamic State of Iraq and the Levant also translated as the ISIL - Islamic State of Iraq and Syria that a few months ago won the city of Mosul in Iraq. That is probably the first time the world heard about them.

Yet the story of these extremists whose leader Abu al-Baghdadi is much more complex than the simple idea of terrorists who kill the cruel way they are standing in the way to create a Caliphate after almost the entire Middle East and North Africa.

As has created this danger, the organization that war in Syria, Iraq and Libya and which draws members from all over the Islamic world, come to die through the deserts of Iraq and Syria, although we had never heard of al-Baghdadi, or thought they would give up prospects of his life in London, Berlin, Sarajevo or Pristina and finish dead in a strange land, far from such obscure bodies left in the sand to disappear on their own. Abu al-Baghdadi, from city of Samarra in Iraq, described as a quiet boy who studied and graduated Islamic Studies at the University of Baghdad in 2004 ended in camp Buca, which are believed to have suffered a radical change. Al-Baghdadi, after the US entry into Iraq in 2003, is one of the founders of the military group called the Army of the Sunni community. No information on their armed actions, but the US military has arrested and imprisoned in military holding camp Buca from February to December 2004. Disclosing mysterious biography of al-Baghdadi gives escaped expert CIA Edward Snowden who claims Al Baghdadi was arrested as a cover for his withdrawal from the public and that the long period spent in Israel, in the camp of their secret police Mossad. Prepared for combat actions and planning, and for speaking and public relations. The purpose of this, according to Snowden is creating strong Sunni structure to fight the other Shiite party. After leaving the camp, prison Buca-Baghdadi al slowly becoming an important structure in the world of Islamic radicals. After the killing of Osama Bin Laden in Pakistan on May 2, 2011, alBaghdadi announces mourning and respect for Osama bin Laden and announced revenge. The first step was a terrorist attack in Mosul in August 2011 with 70 victims. On October 4, 2011 the United States became the most wanted terrorists list and offers a reward for his capture or killing of 10 million dollars. Then it becomes a star among Islamists behind successor to Osama bin Laden's, Al Zawahiri. In May 2010 is reported to have set up a separate organization ISIS 
and its leader is al-Baghdadi. Al Qaeda is slowly falling into shadow. Unless mentioned in Mosul presumably another 29 terrorist actions organized by ISIS.

Only few have heard of Sykes-Picot Agreement. What is it: It is assumed that European dignitaries met in 1916 to divide the Ottoman Asia among themselves Britain and France are given freedom to build their own countries in the region to conquer enemies. As a favorable opportunity, with deep and lasting roots, is recognized option for inducing and maintaining conflict between Shiites and Sunnis, managed by Britain and France.

It is assumed that the then British ambassador in Cairo government in Mecca and promised support for Arab Kingdom, and in return asked for help in the fight against the Ottomans, or the Turkish Empire. But that's not all encounters lack unity and support for the same. When Britain tried to implement its action plan and Sunni in Syria, in Damascus, the French responded with invasion, allied with the Shiites and imposing their own interests. Some Arab states have found ways well in this fight for supremacy between Britain and France, while others pay the price of their losses with increased repression and exploitation of its territory, as compensation for previous losses. Just a few weeks after their first actions to create the Caliphate in Iraq and Syria, ISIS reminiscent of those roots, published a picture which is called "End-Picot - Sykes agreement ". When it comes to ISIS, the connection can be much deeper and darker than assumed. Recently the British intelligence service MI6 published interview with the head of Saudi intelligence. According to that report Saudi Arabia provided major disagreements and clashes between Shiites. The Shia Muslims who are the majority, or power in Iran, Syria and Bahrain and have strict rules in the implementation of Islam founded on Sharia, imam right which is superior over justice, state system. In many Arab states, Kuwait, Saudi Arabia, Qatar, Libya etc. majority rule is moderate Sunni religious. According to the origin of the President of Syria, Assad, Syria is a country where Shiite rule, and the fall of Saddam Hussein who is a member of the Sunnis, led to strengthening the Shiites in Iraq. The last 10 years, Saudi and Qatar foreign policy favored the destabilization of countries by financing those Shiite Sunni extremists. In Saudi Arabia and Qatar, this is probably the biggest mistake that they can do.

The proverb "The enemy of my enemy is my friend" is known to centuries. From day when Iraq after the fall of Saddam Hussein, is controlled by Shiites, since there is a need for funding of Sunnis and helping Sunni extremists of al Qaeda against Shiites.

\section{THE ERROR IN IRAQ STRAINED RELATIONS BETWEEN SUNNI AND SHIA}

At the time when the Iraqi government is Prime Minister Nuri al-Maliki, Iraq moves from dictatorship Sunni dictatorship of Shiites. Sunnis have been repeatedly accused and punished for acts that are copied Saddam Hussein, although they as a community it had nothing. Terrorist attacks on Shiites against them were tolerated, although left behind several thousand victims. The intention to create a conflict that would weaken and eliminate Al Qaeda turned into chaos does not control anyone. Things grew worse in 2011, when several provinces of Sunnis voted for partial autonomy or full independence from Iraq Shiites, linked as it hosts call to open war. Shias related to Iraq through Syria and Iran are not left this Sunni intend to develop. Created a climate in which Shiites did not believe in the Iraqi authorities to be able to cope with the challenge and find the Sunnis for independence so that their leaders have received massive support from home and out of things to take into their own hands and create a state which is strong and controlled. Sunnis, in turn experienced this as prelude to war, and turned to local religious leaders who believe, as al-Baghdadi. Publishes a religious war against the Shiites and Kurds, as well as against Syria and Assad are hated enemies of the United States expecting and receiving initial silence from the West after the system: Assad is our common 
enemy and Al Baghdadi weakens fighting it in a way that the US can to implement .On April 8, 2013 Al Baghdadi his declaring war on Assad and Syria, and announced the creation of an Islamic religious caliphate-ISIS which is organized according to the strictest rules of Sharia, religious laws. This leader of the Syrian Islamists Al Zawahiri who fought against Assad responds with indignation and requires him to hold on to its territory in Iraq. In 2014, there was a struggle for leadership in the city where Al Baghdadi Hand won victory. After this event he takes a series victory against the military actions of Iraq taking away part of the northern Iraqi putting it under his control. Many who lived for years in a desperate situation in Iraq and Syria ISIL seen phenomenon that gives hope that it will not be bad as before, so their approach depressed youth's suddenly become strong and significant in their environments.

All are known to Saudi Arabia funds associated with the activities of terrorist groups such as ISIL and al Qaeda. ISIL has its centers of finance are located in Qatar and Saudi Arabia. Financed by drug trafficking, extortion and robbery. Create extremely radical sectarian community in which dangle and kills slightest violation of the Koran, measured according to their criteria.

Many of the people in Iraq expected change for the better with the fall of Saddam, and lived to disappointment and chaos in Iraq, killings and bombings which until now have been around 50,000 killed after the fall of Saddam. Religious leaders of these states accuse the government in Baghdad and the US, and it is to hate all those addresses.

\section{CONCLUSION}

Link which connects NATO and the UN are best seen from the Preamble of the Washington Treaty (North Atlantic Treaty) where NATO stipulate that the UN Charter is the framework in which they operate NATO. The right of the Allies to take certain actions that they believe would be necessary for their individual or collective self-defense is set out in Article 5 of the Washington Treaty, which in turn refers to Article 51 of the UN Charter.

The terrorist attacks on the United States in 2001 were the reason for the change of geopolitical relations in the world and the US to take the lead in the fight against terrorism globally. The fight against terrorism includes destruction of camps for training terrorists, direct attacks terrorist cells and indirect war. This indirect war against terrorism amounts of research and pressure of governments, organizations and individuals who support terrorist organizations, and means and financial assistance to the countries participating in the antiterror war, increasing the level of police and intelligence cooperation.

The challenges that need to handle the Alliance in the years to come do not differ much from those before sixty years ago, when was formed the Alliance, who interested countries on security issues, some challenges still quite new. The challenges that threaten the interests of the Euro-Atlantic community: terrorism, weapons of mass destruction, the threat of ballistic missiles, conventional armed forces, cyber-attacks, energy security and climate change.

\section{References}

Public Diplomacy Division NATO (2006). Manual NATO. Part I: Introduction to Alliance: Basic security tasks NATO;

Forum for Security and Democracy. NATO Handbook (2009). Chapter 29: NATO's relations with the United Nations, Belgrade 2009, 255-259;

Novakovic, I. (2010). Western Balkans Security: Multinational Operations - NAT0, 25-37;

Ružin N. NATO in contemporary international relations (2010), the phenomenon of global terrorism, Skopje 2010; 
Aleksoski S. (2011). The application of the provisions of international law on the use of armed force in dealing with terrorism. Corporate International Slavic University "GR Derzhavin "- Sveti Nikole Collection of scientific papers: International dialogue: east - west, 1-10;

Haji-Janev M. Legality of the war against terrorism in the name of the right of self-defense and self-defense right early. Contemporary Macedonian Defense, Defense RM, 43-60, Retrieved March 102014.

http://www.morm.gov.mk/wp-content/uploads/2013/10/Sovremena-makedonska-odbrana-br_11.pdf;

http://www.nato.int/cps/en/natohq/topics_49192.htm

AGHANISTAN INTERNATIONAL SECURITY ASSISTANCE FORCE: Troop numbers and contributions (2014). http://www.isaf.nato.int/troop-numbers-and-contributions/index.php;

Novakovic, I. (2010). Western Balkans Security: Multinational Operations - NAT0, 25-37.

Orlic, D. (2009). Sixty years of transformation NATO 2009: PART III: International policy and international relations, FPN, 529-55 